\title{
Responses of split application of nitrogen on the performance of Kharif rice (Oryza sativa L.) in Terai zone of West Bengal
}

\section{PARTHA SARATHI PATRA, SHYAMAL KHEROAR, ASHOK CHOUDHURY AND RAJESH SAHA}

Received : 23.08.2017; Revised : 06.11.2017; Accepted : 16.11.2017

\author{
MEMBERS OF RESEARCH FORUM: \\ Corresponding author : \\ SHYAMAL KHEROAR, All India \\ Network Project on Jute and Allied \\ Fibres, Uttar Banga Krishi \\ Viswavidyalaya, Pundibari, Cooch \\ BEHAR (W.B.) INDIA \\ Email: kheroarshyamal@gmail.com \\ Co-authors : \\ PARTHA SARATHI PATRA, \\ Regional Research Station \\ (U.B.K.V.), Terai Zone, Cooch \\ BEHAR (W.B.) INDIA \\ Email: parthaagro@gmail.com
}

\section{ASHOK CHOUDHURY,}

Department of Soil Science and Agricultural Chemistry, Uttar Banga Krishi Viswavidyalaya, Pundibari,

Cooch, BEHAR (W.B.) INDIA

Email: ashokc540@gmail.com

RAJESH SAHA, Department of Agronomy, Uttar Banga Krishi Viswavidyalaya, Pundibari, Cooch, BEHAR (W.B.) INDIA

Email: rajeshsaha61@gmail.com

\begin{abstract}
Summary
A field trial had been conducted to see the responses of split application of nitrogen on the performance of Kharif rice comprising of 5 treatments $\left(\mathrm{T}_{1}=50 \% \mathrm{~N}\right.$ as basal $+50 \% \mathrm{~N}$ at active tillering, $\mathrm{T}_{2}=50 \% \mathrm{~N}$ as basal $+25 \% \mathrm{~N}$ at active tillering $+25 \% \mathrm{~N}$ at panicle initiation, $\mathrm{T}_{3}=25 \% \mathrm{~N}$ as basal $+25 \% \mathrm{~N}$ at active tillering $+25 \% \mathrm{~N}$ at panicle initiation $+25 \% \mathrm{~N}$ at flowering, $\mathrm{T}_{4}=40 \% \mathrm{~N}$ as basal $+30 \% \mathrm{~N}$ at active tillering basal $+30 \% \mathrm{~N}$ at panicle initiation and $\mathrm{T}_{5}=100 \% \mathrm{~N}$ as basal) using Randomized Complete Block Design (RCBD) with 4 replications in Terai zone, Cooch Behar, West Bengal during 2015 and 2016. The experimental results showed that all the growth and yield attributes were found to be highest where nitrogen was applied in four equal split $\left(\mathrm{T}_{3}\right.$ ) followed by $\mathrm{T}_{2}$ and $\mathrm{T}_{4}$. Higher growth and yield attributes ultimately helped in producing 6.98 and 9.22 per cent more grain yield in $\mathrm{T}_{3}$ over $\mathrm{T}_{2}$ and $\mathrm{T}_{4}$, respectively. 430 to $820 \mathrm{~kg} \mathrm{ha}^{-1}$ yield reduction has been found when 100 per cent nitrogen applied as basal in comparison with splitting of nitrogen in two $\left(\mathrm{T}_{1}\right)$ and four equal parts $\left(\mathrm{T}_{3}\right)$.
\end{abstract}

Key words : Rice, Nitrogen, Split application, Yield, Economics

How to cite this article : Patra, Partha Sarathi, Kheroar, Shyamal, Choudhury, Ashok and Saha, Rajesh (2017). Responses of split application of nitrogen on the performance of Kharif rice (Oryza sativa L.) in Terai zone of West Bengal. Asian J. Soil Sci., 12 (2) : 265-270 : DOI : 10.15740/HAS/AJSS/12.2/265270. 